\title{
DAILY BLENDED MICROWAVE AND INFRARED SEA SURFACE TEMPERATURE COMPOSITION
}

\author{
Gutemberg Borges França ${ }^{1}$, Rosa Cristhyna de Oliveira Vieira Paes ${ }^{1}$, \\ Antônio do Nascimento Oliveira ${ }^{2}$, Bianca Couto Ruivo ${ }^{1}$ and Angelo Sartori ${ }^{3}$
}

\begin{abstract}
A simple system for daily cloud free sea surface temperature (SST) composition based on thermal AVHRR and microwave TMI data is presented in this paper. Barnes' objective analysis is applied as an interpolator to merge these two data sources, which have different spatial and temporal resolutions in a daily SST composition and in a regular grid product. Three comparisons were carried out as follows. First, in situ SST (daily average) measurements from eleven PIRATA's (Prediction and Research Moored Array in the Tropical Atlantic) buoys were compared. The correlation coefficients results varied from 0.89 to 0.99, and RMSE, MAE and MBE values have not exceeded 0.57 for period from 2002 to 2010. Second, comparisons between daily SST composition and average daily in situ SST collected from twenty three drifting buoys for the period from May 2008 to October 2010. The statistics results are $0.94,0.25,0.19$ and -0.002 for correlation, RMSE, MAE and MBE, respectively. Third, SST (daily average) time series generated by OSTIA project was compared. The temporal and spatial RMSE (considering the study area) values ranged from approximately $0.21^{\circ} \mathrm{C}$ to $1.50^{\circ} \mathrm{C}$ and its average was $0.47^{\circ} \mathrm{C}$ for the period from April $1^{\text {st }} 2006$ to December $31^{\text {st }} 2010$. Besides, an investigation about the influence of the data homogenization in the SST interpolation is discussed. Validation results are quite consistent (with SST composition accuracy less than $1.0^{\circ} \mathrm{C}$ ). Thus, aiming to fulfill the numerical oceanographic model assimilation purposes and other oceanographic features studies, the developed SST product may be recommended as a candidate.
\end{abstract}

Keywords: oceanography, objective analysis, satellites.

RESUMO. Este trabalho apresenta uma metodologia para geração de composições diárias de temperatura da superfície do mar (TSM) sem contaminação de nuvens, baseada em dados termais do AVHRR e micro-ondas do TMI. A análise objetiva de Barnes é utilizada como interpolador para mesclar estas duas fontes de dados, que possuem diferentes resoluções espacias e temporais, e gerar uma composição diária de TSM em grade regular. Três tipos de comparações foram feitas com esta composição de TSM, conforme descrito a seguir. 1) Comparação com medidas in situ de TSM (média diária) de onze bóias do PIRATA. Os coeficientes de correlação variaram de 0,89 a 0,99, e os RMSE, MAE e MBE não excederam 0,57 para o período entre 2002 e 2010. 2) Comparação com medidas in situ de TSM (média diária) de vinte e três boias de deriva do PNBOIA para o período entre Maio de 2008 e Outubro de 2010. Os resultados das estatísticas foram: 0,94, 0,25, 0,19 e -0,002 para a correlação, RMSE, MAE e MBE, respectivamente. 3) Comparação com uma série temporal de TSM gerados pelo projeto OSTIA. A faixa dos valores do RMSE (considerando a área de estudo) variou aproximadamente entre $0,21^{\circ} \mathrm{C}$ e $1,50^{\circ} \mathrm{C}$ e sua média foi de $0,47^{\circ} \mathrm{C}$ para o período de 01 de Abril de 2006 a 31 de Dezembro de 2010. Uma investigação sobre a influência da homogeneização das diferentes fontes de dados antes do processo de interpolação é discutida. Os resultados da validação da TSM são consistentes (com uma acurácia menor que 1,00).

Palavras-chave: oceanografia, análise objetiva, satélites.

\footnotetext{
${ }^{1}$ Universidade Federal do Rio de Janeiro (UFRJ), Departamento de Meteorologia, Laboratório de Meteorologia Aplicada (LMA), Campus Cidade Universitária, 21941-916 Rio de Janeiro, RJ, Brazil. Phone: +55(21) 2598-9524 - E-mails: \{gutemberg,rosa,bianca.ruivo\}@Ima.ufrj.br

${ }^{2}$ Fundação ABC Pesquisa e Desenvolvimento Agropecuário (FABC), Setor de Agrometeorologia (SMA), Rodovia PR-151 km 288, 84165-700 Castro, PR, Brazil. Phone: +55(42) 3233-8600 - E-mail: antonio.oliveira@fundacaoabc.org.br

${ }^{3}$ Petrobras Health, Safety, Energy, Efficiency and Environment Sector, Av. Nilo Peçanha, 151, 4th Floor, Centro, 20020-904 Rio de Janeiro, RJ, Brazil. Phone: +55(21) 3229-7904 - E-mail: angelosartori@petrobras.com.br
} 


\section{INTRODUCTION}

Sea surface temperature (SST) plays an important role to model the surface energy flux and to understand the ocean-atmosphere interaction. This parameter is one of the main indicators of climate variability (Barton, 1995). It is also crucial to determine weather and global climate conditions.

SST, moreover, is of great importance in the initialization of numerical models of weather, climate and ocean circulation prediction once it not only allows better refinement of forecasting results but also contributes to the understanding of oceanatmosphere dynamics.

The use of remote sensing to estimate SST has become important once in situ measurements carried out by ships and buoys have temporal and spatial discontinuities. Satellite remote sensing provides the generation of high temporal and spatial resolution multispectral data. These data are regularly obtained and have a wide range of hundreds of kilometers. Although there are advantages to estimate SST data via remote sensing, two main issues jeopardize infrared data use: cloud cover and radiation atmosphere attenuation. Considering that the Earth's surface is normally covered by a great amount (approximately $50 \%$ ) of cloud at one time (Paltridge \& Platt, 1976), for reliable results from the retrieval of surface characteristics using infrared and visible remotely-sensed data absolute, cloud-free pixels are required.

Regarding the existent orbital platforms, SST can be estimated through sensors placed at bands of the electromagnetic spectrum in the infrared and microwave. AVHRR/3 (Advanced Very High Resolution Radiometer) is an instrument aboard of satellites series NOAA (National Oceanic and Atmospheric Administration) NOAA 15, NOAA 16, NOAA 17, NOAA 18 and NOAA 19, which uses a scanning radiometer capable of detecting energy from land, ocean and atmosphere. This tool operates with six spectral bands arranged in the regions of visible and infrared electromagnetic spectrum (Goodrum et al., 2000). Concerning SST estimation via microwave data, the satellite called TRMM (Tropical Rainfall Measuring Mission) - Microwave Imager (TMI) is used. TRMM was launched in December, 1997, having an orbital inclination of $53^{\circ}$ and altitude $350 \mathrm{~km}$, an equatorial orbit that ranges from $40^{\circ} \mathrm{N}$ to $40^{\circ} \mathrm{S}$ and a spatial resolution of $0.25^{\circ}$ ( $\sim 27.75 \mathrm{~km})$. Although AVHRR data have high spatial resolution and are influenced by cloud cover, TMI data are barely influenced by atmospheric attenuation.

SST-AVHRR represents the skin SST (at depth within a superficial thin layer of approximately $500 \mu \mathrm{m}$ ) and its estimation is based upon algorithm Multi Channel Sea Surface Temperature (MCSST) (McClain \& Pichel 1985; McClain, 1989). MC-

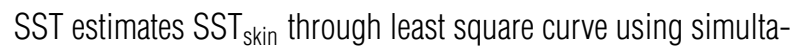

neous data from in situ SST (approximately 1 meter deep) collected via buoys (moored, drifting and ships) and bright temperatures recorded through AVHRR sensor aboard NOAA platforms. On the other hand, SST estimation via microwave data in fact it represents the sub-skin SST at approximately $1 \mathrm{~mm}$ depth (Donlon et al., 2002; Kawai \& Wada, 2007) - is based on the algorithm that calculates SST through multiple linear regression, estimated from a geophysical model to different frequencies and polarizations. This process is based on the methodology developed by Waters et al. (1975). As far as merge different remotely sensed data is concerned, a homogenization is required. Stark et al. (2007) have been successfully merged remotely sensed data (infrared and microwave) and in situ SST measurements to generate a daily accurate SST field. Based on that, aiming at a cloud free SST field, microwave and thermal infrared data fusion is rather plausible. The Objective Analysis (OA) scheme developed by Barnes (1964) has been widely used and recommends generating regular grid and is employed in the present paper. Scolar et al. (1986) present results showing that the performance in the interpolation process of Barnes' method is superior to those using first and second degree polynomial interpolations.

Concerning the necessity of assimilation of SST fields by numerical models of ocean circulation as well as oceanographic features monitoring included in the issues of Oceanographic modeling and Observation Network (Rede de Modelagem e Observação Oceanográfica - REMO) established in Brazil, the objectives of the present work are further described.

\section{OBJECTIVE}

The objectives of this work are:

a) to present a method to obtain daily cloud free SST composition in a regular grid of $0.05^{\circ}$ by testing the sub optimal interpolation technique (Barnes, 1964) to AVHRR (Advanced Very High Resolution Radiometer) data from NOAA (National Oceanic and Atmospheric Administration) satellites series and TMI (Microwave Imager) data from TRMM (Tropical Rainfall Measuring Mission);

b) to make intercomparison with SST field produced by OSTIA's project, aiming to evaluate the influence of the data homogenization used by Stark et al. (2007), which taking into account the differing sensors measure the SST, as early mentioned, at different depths and sensors characteristics;

c) to compare SST from method proposed here and in situ SST measurements from moored and drifting buoys. 


\section{MATERIALS AND METHODS}

\section{a) Applied Data}

Thermal infrared data from satellites NOAA 18 and 19 were used to produce the daily SST fields. Originated from NAVOCEANO MCSST data set and provided by PODAAC (Physical Oceanography Distributed Active Archive Center), product level 2 was selected. These data have a spatial resolution of $0.081^{\circ}$ $(\sim 9 \mathrm{~km})$ (PODAAC, 2010). The microwave SST data generated by TRMM/TMI was also used here. These data are daily made available, have global coverage and are separated in ascending and descending orbit segments with spatial resolution of $0.25^{\circ}$ ( 27.75 km) (REMSS, 2010).

The study area lies between latitudes $45^{\circ} \mathrm{S}$ and $15^{\circ} \mathrm{N}$ and longitudes $70^{\circ} \mathrm{W}$ and $15^{\circ} \mathrm{W}$. It was selected for fulfilling Brazilian Navy and REMO interests related to the periods from 2002 to 2010. In order to validate results daily average in situ SST data collected at 1 meter depth from a set of 11 moored buoys of PIRATA (Prediction and Research Moored Array in the Tropical Atlantic) project and 23 drifting buoys of PNBOIA project were used. The buoys are placed as shown in Figure 1.

\section{b) Methodology}

Figure 2 schematically shows the methodology applied to generate $0.05^{\circ}$ daily cloud free blended (infrared and microwave) SST products (approximately $5.5 \mathrm{~km}$ ). The first step refers to SST: AVHRR and TMI data input (discharging TMI pixels less than $25 \mathrm{~km}$ far from the coast line). The second one is the interpolation using Barnes (1964) objective analysis technique. This interpolation is iterative and encompasses three steps:

Step 1: weight estimation $\left(w_{m}^{(0)}\right)$ according to the distance between observation point $\left(x_{n}, y_{n}\right)$ and grid point $(i, j)$, as represented by the Equation (1):

$$
w_{m}^{(0)}=\exp \left(-\frac{r^{2}}{k}-\frac{\tau^{2}}{v}\right)
$$

where $r$ is the Euclidean distance, $\tau$ is the interpolation time, $k$ is Gaussian filter parameter in relation to space and $v$ is Gaussian filter parameter in relation to time.

Step 2: SST interpolation using Equation (2) - first Barnes' method iteraction:

$$
f_{i}^{(1)}=\frac{\sum_{j=1}^{M} w_{i j} f_{j}^{0}}{\sum_{j=1}^{M} w_{i j}}
$$

where $f_{j}^{0}$ represents the values at the observation points placed inside influence radius, herein considered $0.15^{\circ}$.

Step 3: SST interpolation using Equation (3):

$$
f_{i}^{(n+1)}\left(f_{j}^{0}, w_{i j}\right)=f_{i}^{(n)}+\frac{\sum_{m=1}^{M} w_{i j}\left(f_{j}^{0}-f_{j}^{(n)}\right)}{\sum_{j=1}^{M} w_{i j}}
$$

where $f_{j}^{(n)}$ represents the value obtained at the observation point via bilinear interpolation at the four adjacent grid points collected in the first approximation. If they do not converge, weights are recalculated by using Equation (4).

$$
w_{m}^{(1)}=\exp \left(-\frac{r^{2}}{\alpha k}-\frac{\tau^{2}}{\alpha v}\right)
$$

where $w_{m}^{(1)}$ represents weight correction in function of a convergence parameter $(\alpha)$ applied to control smoothing amount of the field to be produced. The values of $\alpha$ ranged from 0 to 1 . Koch et al. (1983), Mills et al. (1997), Accadia et al. (2003) and Sinha et al. (2006) employ values ranging from 0.2 and 0.5 . In this work, a trying and error procedure was used to determine the optimum Barnes coefficients. Considering the mentioned interval in this work, the coefficients established and utilized for mean distance between the observations, convergence factor in space and convergence factor in time are $0.05,0.1$ and 0.1 , respectively. Then, steps 2, 3 and 4 should be repeated until convergence is achieved. The result is an SST field containing contaminated pixels, i.e. pixels with no SST values attributed either due to lack of data or persistent cloud coverage.

Step 4 is the application of a climatology composed of the last daily generated SST, which is daily updated with only cloud free blended SST pixel, aiming at filling the pixels that were not recovered by Barnes' scheme. Step 4 consists in applying a moving average filter for eliminating possible noises and providing a smoother SST field. It is important to mention that the filtered SST is reused so as to update climatology, as seen in Figure 2.

A thorough process was designed in order to verify the efficacy of this methodology. Three comparisons constitute the process:

1) Comparison between daily generated SST composition and in situ SST data set collected from 11 moored buoys (approximately at 1 meter depth) of the PIRATA project.

According to Minnett (2003), SST data estimated either via remote sensing or SST collected from buoys should be carefully analyzed. SST values collected through remote sensing refer to 


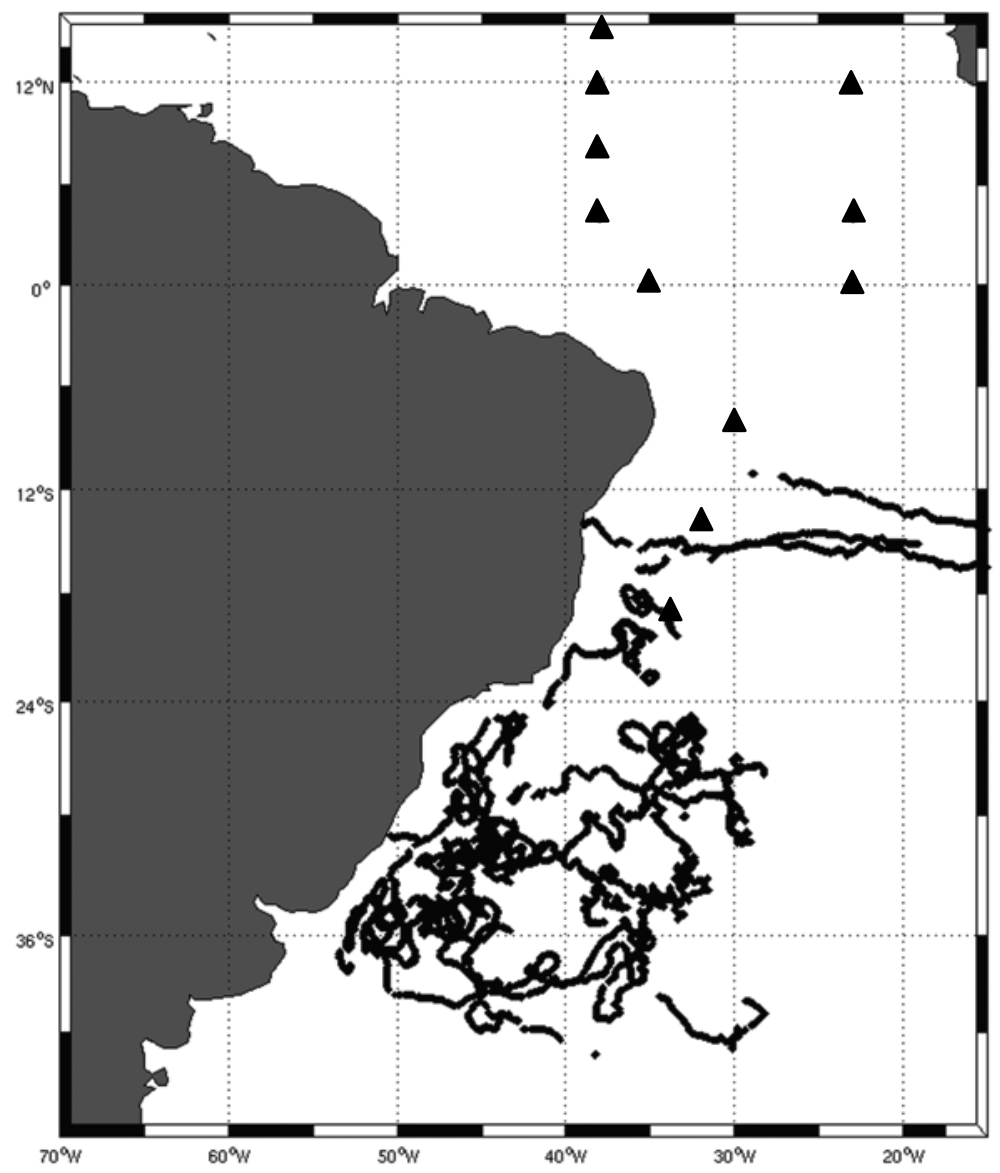

Figure 1 - Buoys distribution map (black triangles and black solid lines represent the 11 moored buoys and the 23 drifting buoys, respectively). The SST data collection period for the drifting buoys is from May 2008 to Oct 2010.

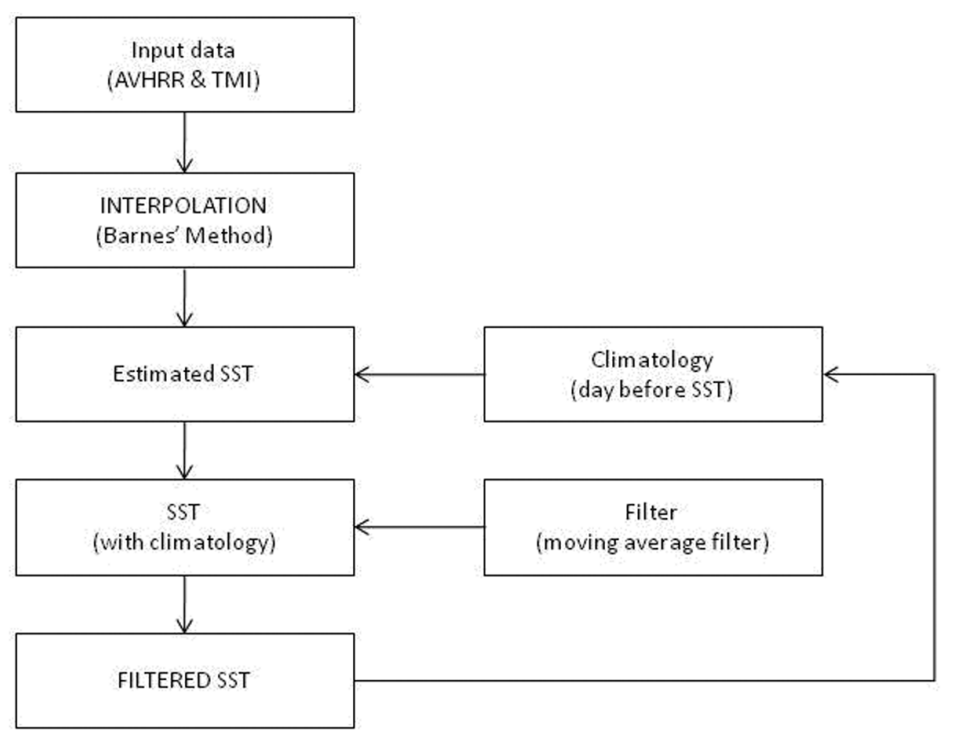

Figure 2 - Daily SST composition scheme. 
the ocean skin layer at about $0.1 \mathrm{~mm}$ depth. In situ (buoys) data are measured at different depths along water column. When compared, this difference in measurement can cause significant divergence due mainly to the effects of the diurnal thermocline ${ }^{1}$ and cool skin².

Minnett (2003) states that the difference between measurements is partially compensated by wind action and temperature variation along the day. The layer is then more homogeneous, and diurnal thermocline and cool skin effects are minimized, making it possible to compare surface and subsurface SST. In the comparison between SST and buoy presented here, it is taken into account that wind speed surface is greater than $6 \mathrm{~m} / \mathrm{s}$ based on results presented by Yokoyama et al. (1995), Donlon et al. (2002), Stark et al. (2007) and Iwasaki et al. (2008). Thus, it ensures that there is no difference between the SST and the near sea surface layer where the buoy temperature sensor is normally disposed.

2) Comparison between daily generated SST composition and in situ SST data set collected from 23 drifting buoys (approximately at 0.30 meter depth) of the PNBOIA project; and

3) Simple comparison between daily SST fields generated in this work and the ones from the Operational Sea Surface Temperature and Sea Ice Analysis - OSTIA project, which uses a similar methodology provided by the United Kingdom Meteorological Office (UKMO) with $0.05^{\circ}$ spatial resolution. The database is a combination of high-resolution infrared sensors (AVHRR-LAC/GAC, SEVIRI and AATSR).

Root Mean Squared Error (RMSE), Mean Absolute Error (MAE), Mean Bias Error (MBE), correlation coefficient (CORR) and Average (Zacharias et al., 1996) area the statistics applied to validate results.

\section{RESULTS}

The results of the daily SST (AVHRR+TMI) composition, generated in this work, were obtained considering a wide spectrum of atmospheric condition during the period from 2002 to 2010. Only for the text completeness, it is worth to mention that the merged SST, in here, does not include data homogenization, such as used by Stark et al. (2007), which taking into account difference sensors characteristics, as aforementioned. Table 1 represents the values of RMSE, MAE, MBE and the correlation coefficients for the comparison between coincident daily SST pixel and in situ SST (daily average) obtained at a depth of $1 \mathrm{~m}$ from eleven PIRATA's buoys. These buoys are distributed in the tropical region at coordinates indicated in Table 1 and Figure 1 (red spot), respectively.

Generally, the results reveal an excellent representative of the real SST field by the daily SST composition where the PIRATA's buoys are disposed in the equatorial study area. The correlation coefficients for all buoys are higher than 0.85 and the values of RMSE, MAE and MBE have not exceeded 0.5 for all in situ measurements, which corroborate the usual accuracy of SST estimation process by remotely sensed data (França \& Carvalho, 2004). It is clearly noted from the results that there are slight fluctuations between the SST compositions versus in situ measurements. The main reasons can be attributed to the spatial resolutions difference of remotely sensed data (AVHRR and TMI), atmospheric effects, no-calibrated buoys sensors, interpolation error, possible difference that could occur between the in situ SST at $1 \mathrm{~m}$ depth and superficial ones. The latter is noted when the SST comparisons (as in Table 1) are made taking into account surface wind speed equal to $6 \mathrm{~m} / \mathrm{s}$ or higher. Such condition has shown slight improvement in overall statistics values since this wind condition will make the skin surface temperature (where the remotely sensed data are acquired) equal to the sea surface temperature at $1 \mathrm{~m}$ depth (where in situ buoys measurements occur).

On the other hand, aiming to evaluate the accuracy of the merged SST field produced in here, a comparison, between in situ SST (daily average) at a depth of $0.30 \mathrm{~m}$ from twenty three drifting buoys, was realized. These buoys were launched in the tropical and mid latitudes and their paths range approximately in the latitude interval from $11^{\circ} \mathrm{S}$ to $42^{\circ} \mathrm{S}$, respectively, during the period from May 2008 to October 2010, as depicted in Figure 1 by black solid lines. Table 2 represents the values of RMSE, MAE, $\mathrm{MBE}$ and the correlation coefficients for the comparison between coincident daily SST pixel and in situ SST (daily average) from PNBOIA project.

Figure $3(a-k)$ shows a comparison among daily SST estimated in this work, OSTIA and in situ SST obtained at $1 \mathrm{~m}$ depth from the eleven PIRATA's buoys during the period from April $1^{\text {st }}$ 2006 to September $31^{\text {st }}$ 2010. Although, as expected, there are SST value's fluctuations among the three SST time series, generally considering a qualitative comparison, the behavior of three SST time series is coherent and quite similar. It is important to mention that the results of the SST time series herein produced are slightly closer to the buoys than the OSTIA ones.

\footnotetext{
${ }^{1}$ Thermocline represents superior layer warming increase throughout day and contributes to surface temperature increase due to a decrease in solar radiation effects in lower layers; thus, it creates a strong gradient of temperature in the first meters of water column.

${ }^{2} \mathrm{Cool}$ skin is heat loss from ocean skin layer to atmosphere.
} 


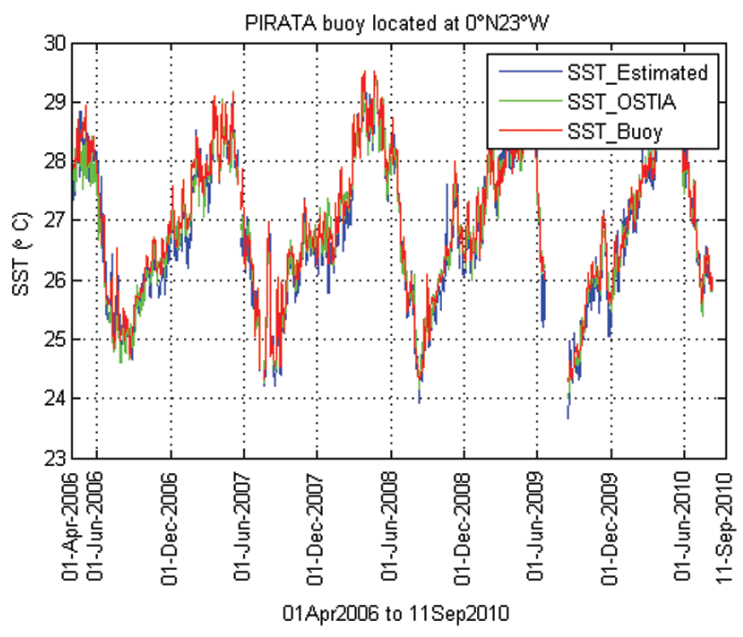

(a)

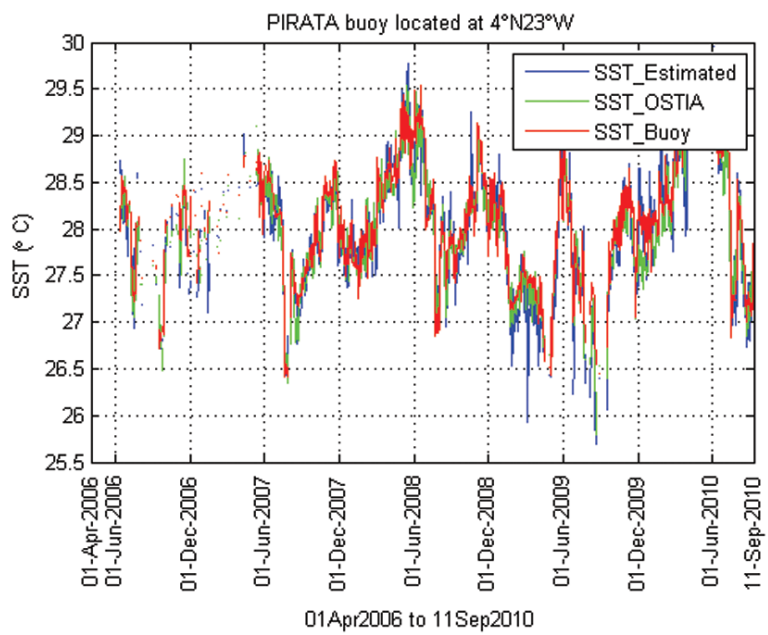

(c)

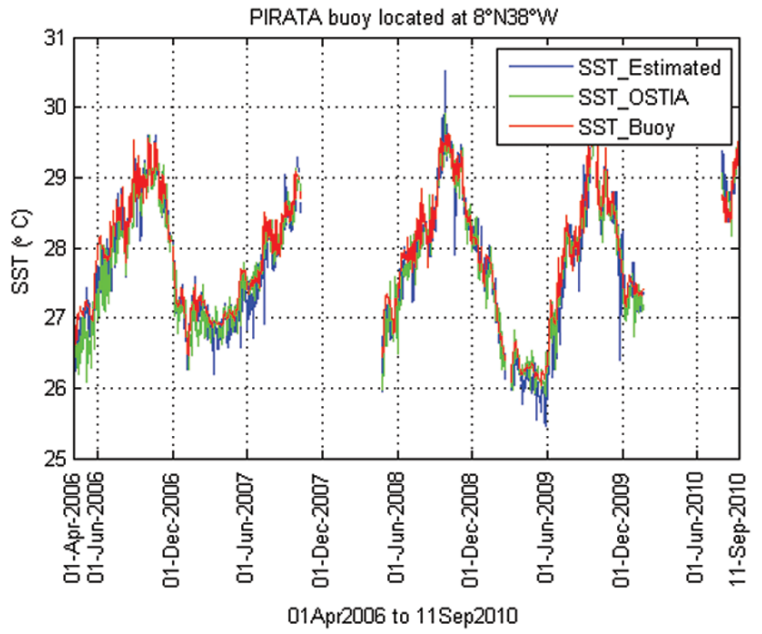

(e)

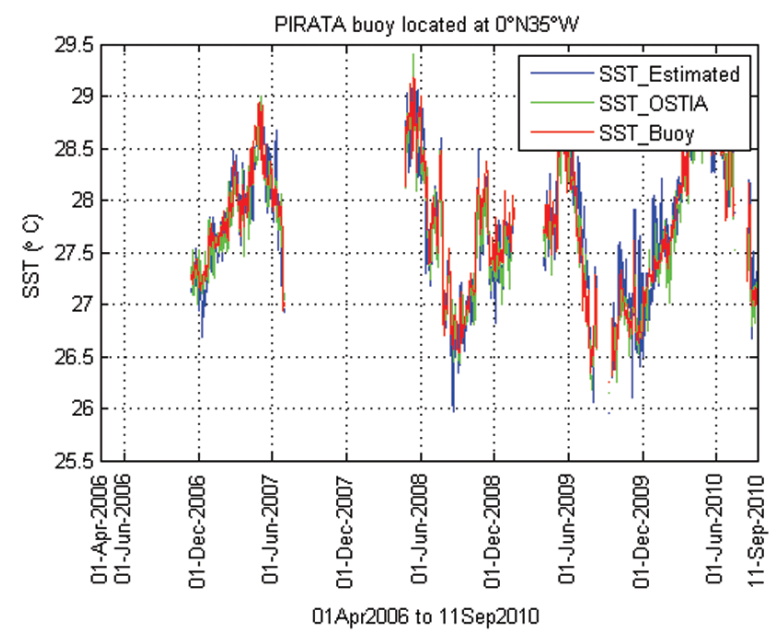

(b)

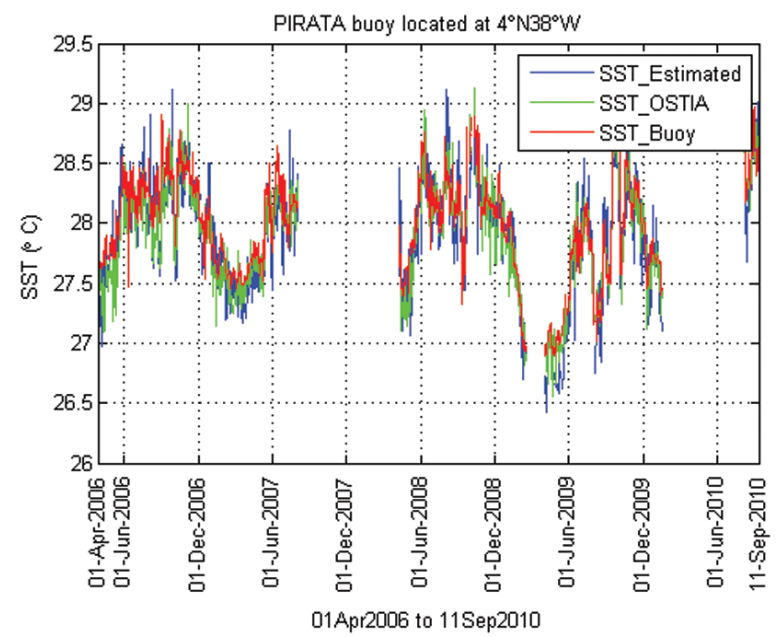

(d)

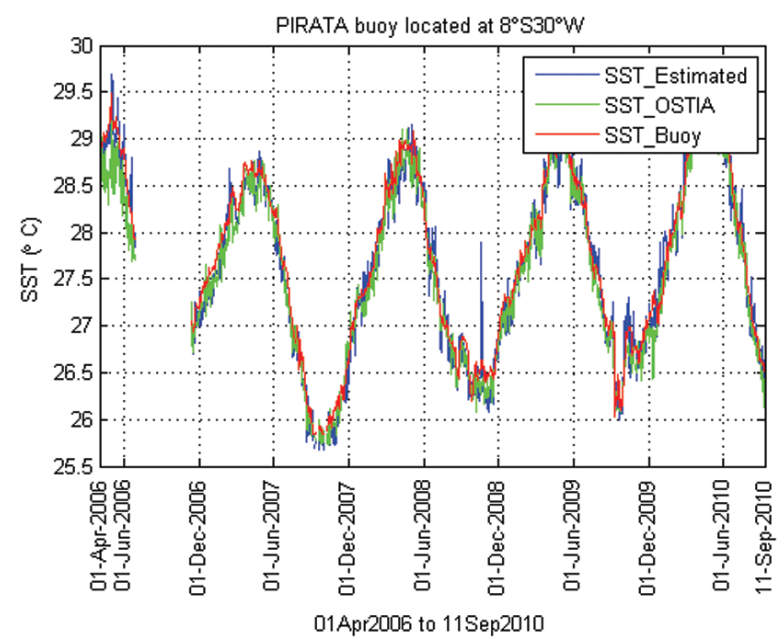

(f)

Figure 3 - (a)-(f) Plot of estimated SST value, SST generated by OSTIA project and SST (1 m depth) collected from the 11 PIRATA project buoys during 04/01/2006 to $09 / 11 / 2010$. 


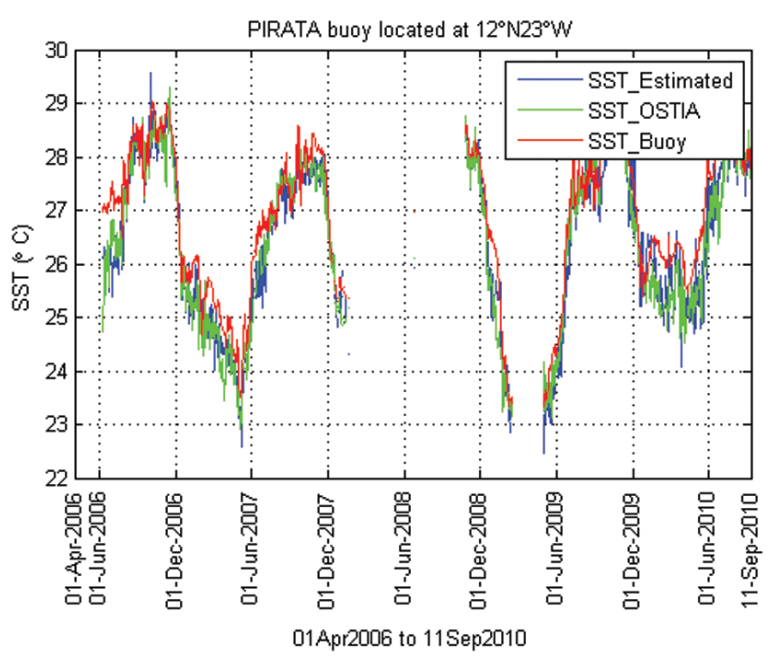

(g)

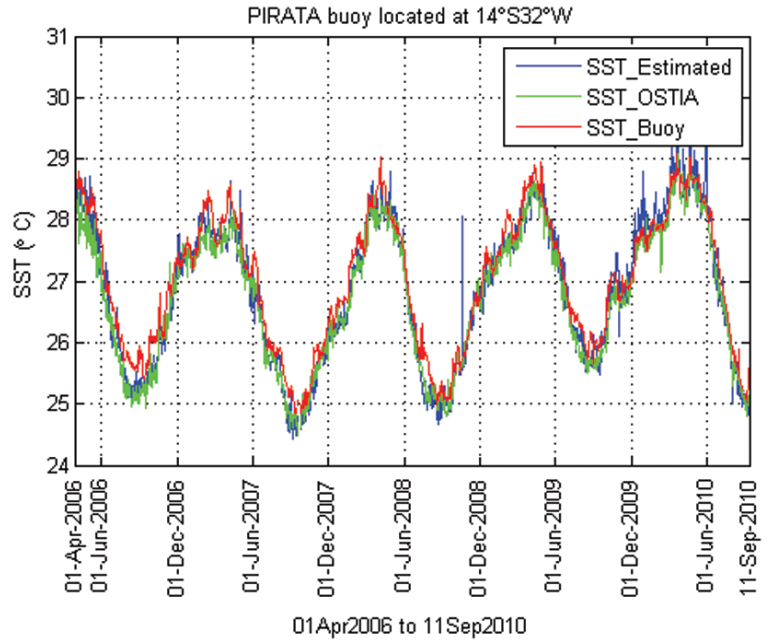

(i)

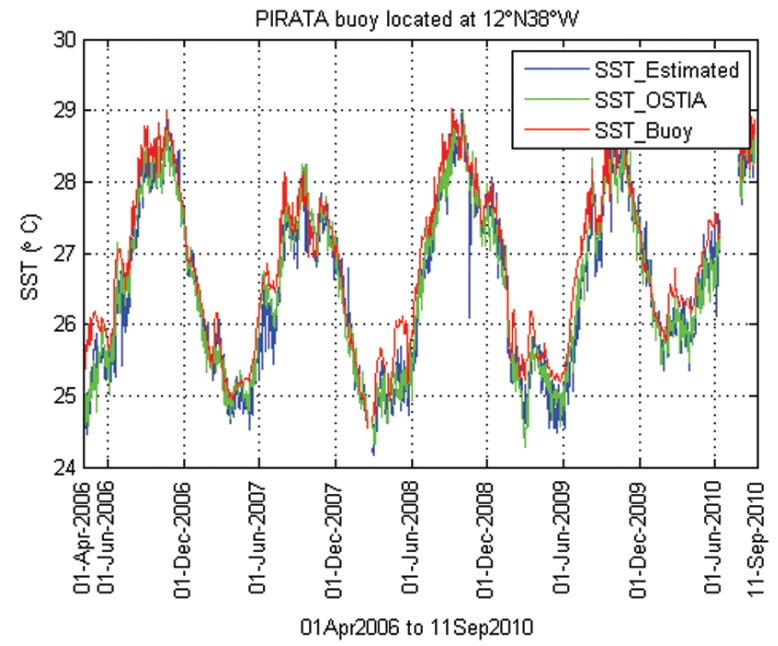

(h)

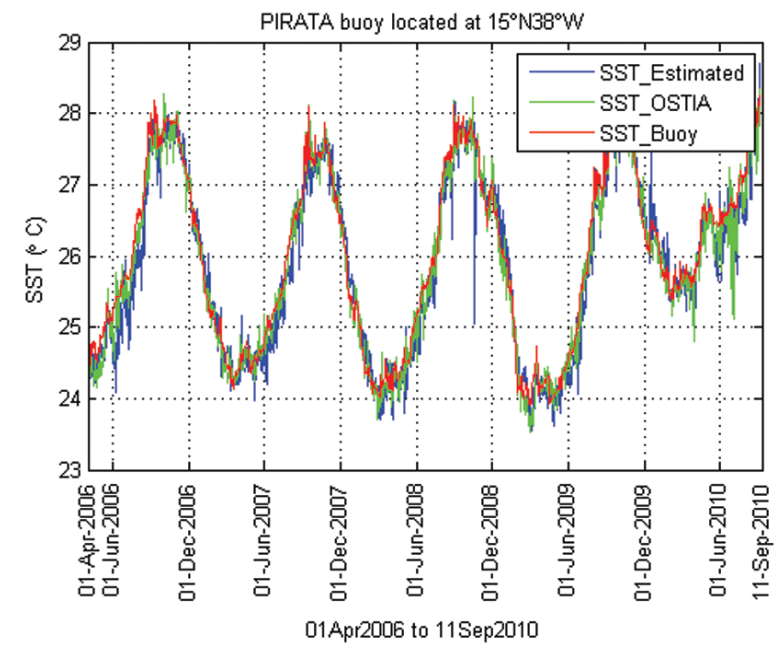

(j)

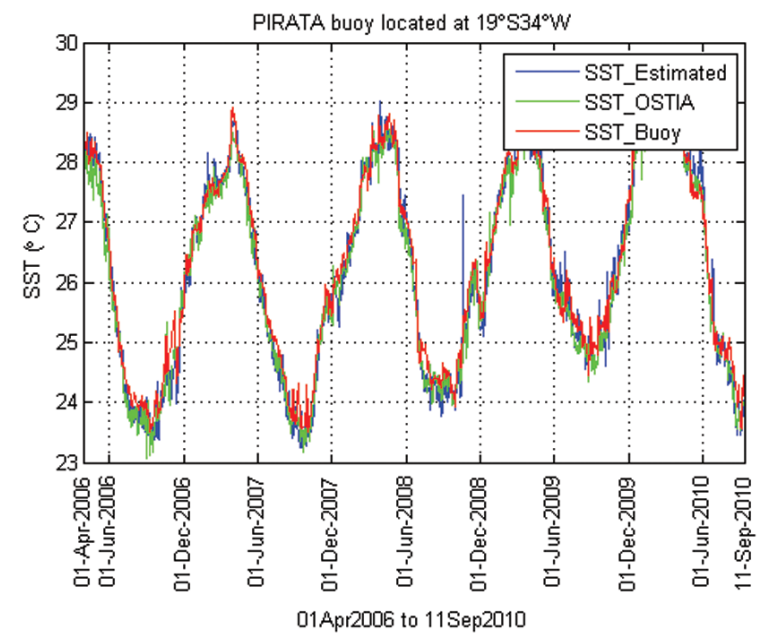

(k)

Figure 3 (continuation) - $(\mathrm{g})-(\mathrm{k})$ Plot of estimated SST value, SST generated by OSTIA project and SST (1 $\mathrm{m}$ depth) collected from the 11 PIRATA project buoys during 04/01/2006 to 09/11/2010. 
Table 1 - Comparison statistics between daily SST composition and average daily in situ SST collected from eleven buoys of PIRATA's project from August 01 ${ }^{\text {st }}, 2005$ to July $31^{\text {st }}, 2006$. The statistics are Mean Squared Error (RMSE), Mean Absolute Error (MAE), Mean Bias Error (MBE), correlation coefficient (CORR).

\begin{tabular}{|c|c|c|c|c|c|}
\hline Buoy Location & Period & RMSE & MAE & MBE & CORR \\
\hline $15^{\circ} \mathrm{N}-38^{\circ} \mathrm{W}$ & $2002-2010$ & 0.32 & 0.24 & -0.13 & 0.98 \\
$12^{\circ} \mathrm{N}-38^{\circ} \mathrm{W}$ & $2002-2010$ & 0.41 & 0.31 & -0.24 & 0.96 \\
$12^{\circ} \mathrm{N}-23^{\circ} \mathrm{W}$ & $2006-2010$ & 0.57 & 0.44 & -0.33 & 0.97 \\
$8^{\circ} \mathrm{N}-38^{\circ} \mathrm{W}$ & $2002-2010$ & 0.27 & 0.21 & 0.10 & 0.96 \\
$4^{\circ} \mathrm{N}-38^{\circ} \mathrm{W}$ & $2002-2010$ & 0.24 & 0.19 & 0.19 & 0.89 \\
$4^{\circ} \mathrm{N}-23^{\circ} \mathrm{W}$ & $2006-2010$ & 0.33 & 0.25 & -0.09 & 0.93 \\
$0^{\circ} \mathrm{N}-35^{\circ} \mathrm{W}$ & $2002-2010$ & 0.24 & 0.19 & -0.04 & 0.93 \\
$0^{\circ} \mathrm{N}-23^{\circ} \mathrm{W}$ & $2002-2009$ & 0.30 & 0.24 & -0.16 & 0.98 \\
$8^{\circ} \mathrm{S}-30^{\circ} \mathrm{W}$ & $2005-2010$ & 0.19 & 0.15 & -0.06 & 0.98 \\
$1^{\circ} \mathrm{S}-32^{\circ} \mathrm{W}$ & $2005-2010$ & 0.32 & 0.25 & -0.16 & 0.97 \\
$19^{\circ} \mathrm{S}-34^{\circ} \mathrm{W}$ & $2005-2010$ & 0.29 & 0.23 & -0.10 & 0.99 \\
\hline
\end{tabular}

Table 2 - Comparison statistics between daily SST composition and average daily in situ SST collected from twenty three drifting buoys for the period from May 2008 to October 2010. The statistics are Mean Squared Error (RMSE), Mean Absolute Error (MAE), Mean Bias Error (MBE), correlation coefficient (CORR).

\begin{tabular}{|c|c|c|c|}
\hline RMSE & MAE & MBE & CORR \\
\hline 0.25 & 0.19 & -0.002 & 0.94 \\
\hline
\end{tabular}

As previously mentioned the interpolation procedure in this work does not take into account the data homogenization to generate the SST field. Therefore, objecting to evaluate the influence of such data homogenization, a pixel-by-pixel intercomparison between SST estimated values considered in this work and SST estimated values of OSTIA's project (which the data homogenization is included in the merging procedure) was realized. Figure 4 spatially displays in the study area the RMSE between OSTIA and the SST produced here. The RMSE varies approximately from $0.21^{\circ} \mathrm{C}$ to $1.50^{\circ} \mathrm{C}$ and its average is 0.47 . The maximum RMSE value appears, as expected, in Brazil-Malvinas current confluence region and also in the regions of upwelling since those regions are characterized by considerable thermal gradient in time (Olson et al., 1988; Piola et al., 2000).

In addition, Table 3 depicts the minimum, maximum and average values of the differences between the buoy SST and SST estimated in this work (Buoy-SST_estimated) and Buoy SST and OSTIA SST (Buoy-SST_OSTIA) during the period from January $1^{\text {st }}$ to $5^{\text {th }}, 2006$. The averages of the differences for eight moored buoys have magnitude of $0.15^{\circ} \mathrm{C}$ and $0.30^{\circ} \mathrm{C}$ for Buoy-SST_estimated and Buoy-SST_OSTIA, respectively. The minimum and maximum values of the Buoy-SST_estimated and Buoy-SST_OSTIA are $-0.91^{\circ} \mathrm{C}$ to $1.38^{\circ} \mathrm{C}$ and $-0.77^{\circ} \mathrm{C}$ to $1.25^{\circ} \mathrm{C}$, respectively. It is noted that the maximum difference values, for both time series, appear in the same buoy that is located at $12^{\circ} \mathrm{N}-38^{\circ} \mathrm{W}$, what may be an indication of no-calibrated sensor in this particular buoy.

In summary, the statistics results - from Figure 4 and Table 3 - suggest that data homogenization does not play such important role in the merged SST here, since SST_OSTIA field is quite similar to one produced by this work.

Figure $5(\mathrm{a}-\mathrm{b})$ shows two samples of daily SST (AVHHR+TMI data) composition generated in this work on January $1^{\text {st }}$ and July $1^{\text {st }}, 2006$. These samples are results from the system developed, tested, implemented and continuously validated for daily SST composition in the REMO project. Currently, this product is generated and systematically made available in the following site: http://www.rederemo.org.

\section{CONCLUSION}

This work has mentioned the importance of SST into the assimilation process by oceanographic model. Nowadays, remotely sensed SST derived is commonly available from orbital platform with global coverage. Thus, it represents the chief source of data considering large geographical areas for model assimilation 


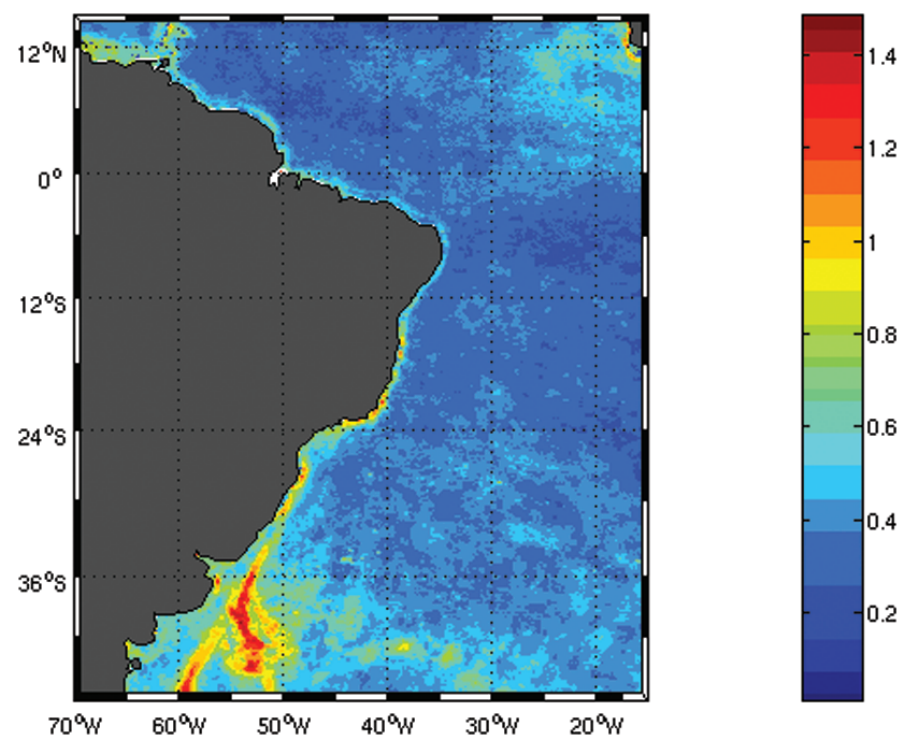

Figure 4 - RMSE field generated from SST estimated values considered in this work and SST estimated values of OSTIA project collected during the period from April 2006 to December 2010.

Table 3 - Maximum, minimum and average values of the differences between the Buoy SST and SST (estimated in this work) and Buoy SST and OSTIA SST for each buoy time series during the period from January $1^{\text {st }}$ to $5^{\text {th }}, 2006$.

\begin{tabular}{|c|c|c|c|c|c|c|}
\hline Buoy & \multicolumn{3}{|c|}{ Buoy-SST_estimated } & \multicolumn{3}{c|}{ Buoy-SST_OSTIA } \\
\cline { 2 - 7 } Location & Min & Max & Average & Min & Max & Average \\
\hline $15^{\circ} \mathrm{N}-38^{\circ} \mathrm{W}$ & -0.67 & 0.83 & 0.12 & -0.34 & 0.54 & 0.14 \\
$12^{\circ} \mathrm{N}-38^{\circ} \mathrm{W}$ & -0.41 & $\mathbf{1 . 3 8}$ & 0.38 & -0.08 & $\mathbf{1 . 2 5}$ & 0.53 \\
$8^{\circ} \mathrm{N}-38^{\circ} \mathrm{W}$ & 0.77 & -0.54 & 0.19 & -0.37 & 1.12 & 0.39 \\
$4^{\circ} \mathrm{N}-38^{\circ} \mathrm{W}$ & $\mathbf{- 0 . 9 1}$ & 0.98 & 0.08 & 0.13 & 0.90 & 0.27 \\
$0^{\circ} \mathrm{N}-23^{\circ} \mathrm{W}$ & -0.55 & 0.89 & 0.24 & $\mathbf{- 0 . 7 7}$ & 1.12 & 0.23 \\
$8^{\circ} \mathrm{S}-30 \mathrm{~W}$ & -0.64 & 0.51 & 0.07 & -0.27 & 0.96 & 0.26 \\
$14^{\circ} \mathrm{S}-32^{\circ} \mathrm{W}$ & -0.67 & 0.77 & 0.16 & -0.19 & 0.97 & 0.42 \\
$19^{\circ} \mathrm{S}-34^{\circ} \mathrm{W}$ & -0.67 & 0.59 & 0.02 & -0.42 & 0.71 & 0.22 \\
\hline
\end{tabular}

purpose. However, there are two main problems to be solved to estimate SST via remotely sensed data, e.g., cloud contamination and its validation. The latter is indispensable in the development of an operational product to fulfill such aforementioned aims.

This work presents a procedure for daily SST composition based on AVHRR and TMI SST using Barnes' approach aiming to remove SST cloud contamination (França \& Cracknell, 1995) and to present the current accuracy of the product by comparing it with two SST datasets, i.e.: a) in situ buoys SST and b) OSTIA SST product. Overall, the results have revealed a good performance of the system. All comparisons carried out in this work between daily SST composition and in situ SST measurements from eleven PIRATA's buoys show that the correlation coefficients vary from 0.89 to 0.99 and RMSE, MAE and MBE values have not exceeded 0.57, considering time period from 2002 to 2010. Similar the latter, comparisons were realized between daily SST composition and average daily in situ SST collected from twenty three drifting buoys for the period from May 2008 to October 2010. The statistics results are $0.94,0.25,0.19$, and -0.002 for correlation, RMSE, MAE and MBE, respectively. It is well known that merging procedure requires the data homogenization when different data sources and time/space resolution are used. This work had purposed an investigation about the influence of the data homogenization when is not included in analysis for the SST merging 


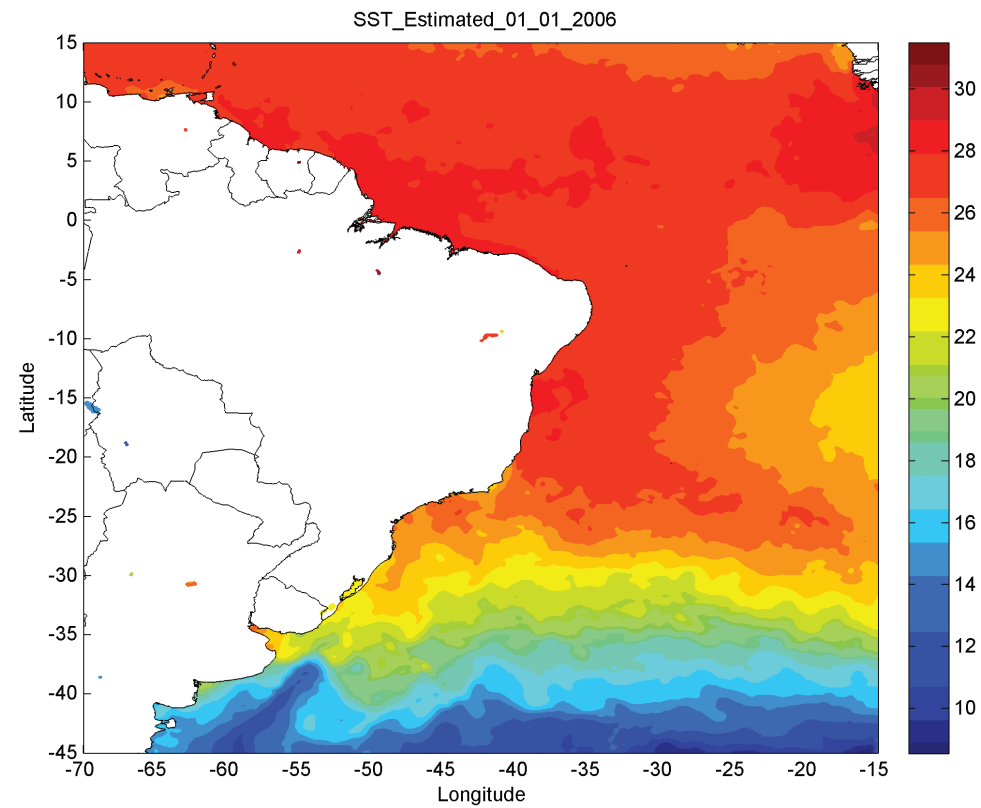

(a)

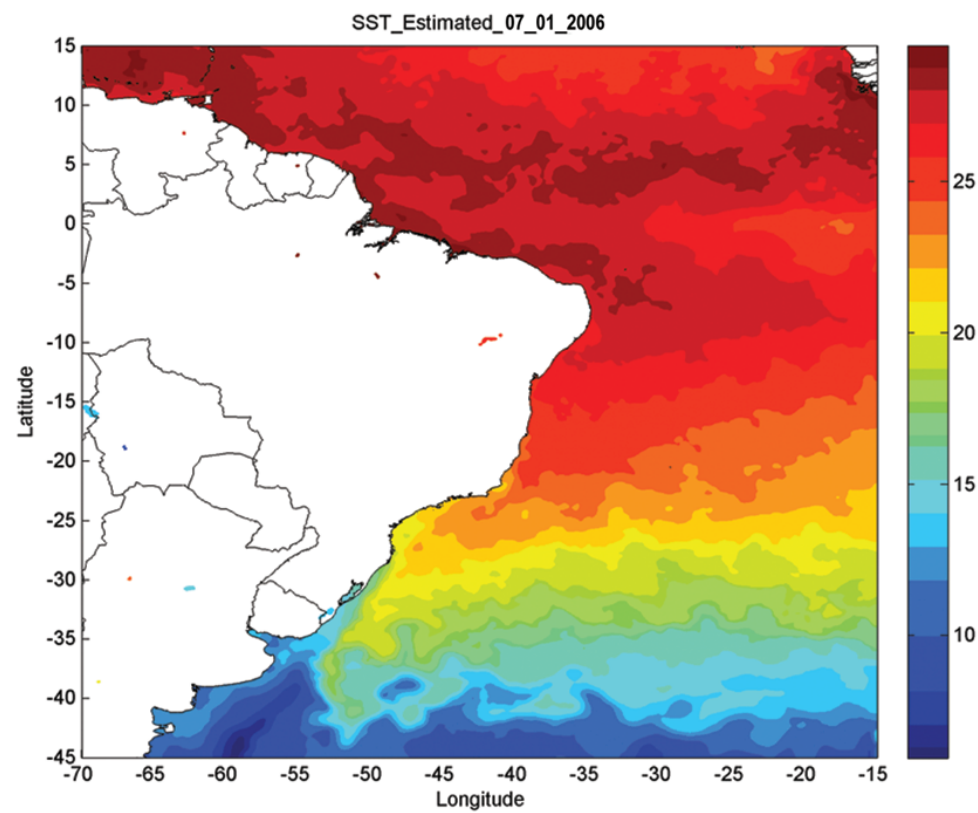

(b)

Figure 5 - (a)-(b) Daily SST compositions obtained on January $1^{\text {st }}$ and July $1^{\text {st }}, 2006$, respectively.

purposes as in this work. The statistics results have clearly indicated that daily SST field produced is quite consistent and, thus, we may mention that the data homogenization does not clearly play a significant influence in the blended SST field, as has done in this work.

Furthermore, a comparison with SST time series generated by OSTIA project shows results with an excellent coherence since the RMSE values vary approximately from $0.21^{\circ} \mathrm{C}$ to $1.50^{\circ} \mathrm{C}$ and its average is 0.47 for the period from April $1^{\text {st }} 2006$ to December $31^{\text {st }} 2010$. Thus, based on result analysis, it may be stated that the developed system can provide a daily SST cloud free product with absolute error less than $1.0^{\circ} \mathrm{C}$. Although the results are reasonable, the validation activities are recommended and should be permanently carried out. Besides, further efforts 
should be carefully done regarding to investigate the errors of the SST retrieval using microwave and infrared remotely sensed data.

\section{ACKNOWLEDGMENTS}

This research has been supported by grant N. 0050.0023117.06.A from CENPES/PETROBRAS.

\section{REFERENCES}

ACCADIA C, MARIANI S, CASAIOLI M, LAVAGNINI A \& SPERANZA A. 2003. Sensitivity of precipitation forecast skill scores to bilinear interpolation and a simple nearest-neighbor average method on high-resolution verification grids. Weather Forecasting, 18: 918-932.

BARNES S. 1964. A technique for maximizing details in numerical weather map analysis. Journal Applied Meteorology, 3: 395-409.

BARTON IJ. 1995. Sattelite-derived sea surface temperature-current status. Journal of Geophysical Research, 15: 8777-8790.

DONLON CJ, MINNETT PJ, GENTEMANN C, NIGHTTINGALE TJ, BARTON IJ, WARD B \& MURRAY MJ. 2002. Toward Improved Validation of Satellite Sea Surface Skin Temperature Measurements for Climate Research. Journal of Climate, 15: 353-369

FRANÇA GB \& CARVALHO WS. 2004. Sea surface temperature GOES-8 estimation approach for the brazilian coast, vol. 25. International Journal of Remote Sensing, 17: 3439-3450.

FRANÇA GB \& CRACKNELL AP. 1995. A simple cloud masking approach using NOAA AVHRR-daytime data for tropical areas. International Journal of Remote Sensing, 9: 1697-1705.

GOODRUM G, KIDWELL K, WINSTON W \& NOAA KLM. 2000. Available on: < http://www.ncdc.noaa.gov/oa/pod-guide/ncdc/docs/klm/ index.htm > . Accessed: Sept. 20, 2010.

IWASAKI S, KUBOTA M \& TOMITA H. 2008. Inter-comparison and evaluation of global sea surface temperature products. International Journal of Remote Sensing, 29(21): 6263-6280.

KAWAI Y \& WADA A. 2007. Diurnal Sea Surface Temperature Variation and Its Impact on the Atmosphere and Ocean: A Review. Journal of Oceanography, 63: 721-744.

KOCH SE, DESJARDINS M \& KOCIN PJ. 1983. An interactive Barnes objective map analysis scheme for use with satellite and conventional data. Journal Climate Applied Meteorology, 22: 1487-1503.

McCLAIN EP \& PICHEL WG. 1985. Comparative performance of AVHRR based multi-channel sea surface temperature. Journal of Geophysical Research, 90: 11587-11601.

MCCLAIN EP. 1989. Global sea surface temperature and cloud clearing for aerosol optical depth estimates. International Journal of Remote Sensing, 10: 763-769.
MILLS GA, WEYMOUTH G, JONES D, EBERT EE, MANTON M, LORKIN $J$ \& KELLY J. 1997. A national objective daily rainfall analysis system. BMRC Techniques Development Report, 1, 30 pp.

MINNETT PJ. 2003. Radiometric measurements of the sea-surface skin temperature: the competing roles of the diurnal thermocline and the cool skin. International Journal of Remote Sensing, 24: 5033-5047.

OLSON DB, PODESTA GP, EVANS RH \& BROWN OB. 1988. Temporal variations in the separation of Brazil and Malvinas Currents. Deep Sea Research Part A. Oceanographic Research, 35(12): 1971-1990.

PALTRIDGE GW \& PLATT CMR. 1976. Radiative processes in meteorology and climatology. Elsevier, NY, 318 pp.

PODAAC (PHYSICAL OCEANOGRAPHY DISTRIBUTED ACTIVE ARCHIVE CENTER). 2010. Sea Surface Temperature Data. Available on: < ftp://podaac-ftp.jpl.nasa.gov/allData/avhrr/L2/navo_mcsst_9km_gac/ docs/avhrr_navoceano.html>. Accessed on Aug. 29, 2010.

PIOLA AR, CAMPOS EJD, MÖLLER Jr 00, CHARO M \& MARTINEZ C. 2000. Subtropical Shelf Front off eastern South America. Journal of Geophysical Research, 105: 6565-6578, doi: 10.1029/1999JC000300.

REMSS (REMOTE SENSING SYSTEMS). 2010. Sea Surface Temperature Data. Available on: <http://www.remss.com/tmi/tmi_description.html>. Accessed on Aug. 29, 2010.

SCOLAR L, SUGAHARA S \& SILVA DMAF. 1986. Comparação entre métodos de análise objetiva. In: I Congresso Interamericano de Meteorologia e IV Congresso Brasileiro de Meteorologia. Proceedings 2: $111-116$.

SINHA SK, NARKHEDKAR SG \& MITRA AK. 2006. Barnes objective analysis scheme of daily rainfall over Maharashtra (India) on a mesoscale grid. Atmosfera, 19: 109-126.

STARK JD, DONLON CJ, MARTIN MJ \& MCCULLOCH ME. 2007. OSTIA: An operational, high resolution, real time, global sea surface temperature analysis system. OCEANS 2007 Europe, pp. 1-4, 18-21, doi: 10.1109/OCEANSE.2007.4302251

WATERS JW, KUNZI KF, PETTYJOHN RL, POON RKL \& STAELIN DH. 1975. Remote sensing of atmospheric temperature profiles with Nimbus5 microwave spectrometer. Journal of the Atmospheric Sciences, 32: 1953-1969.

YOKOYAMA R, TANBA S \& SOUMA T. 1995. Sea Surface effects on the sea surface temperature estimation by remote sensing. International Journal of Remote Sensing, 16(2): 227-238.

ZACHARIAS S, HEATWOLE CD \& COAKLEY CW. 1996. Robust quantitative techniques for validating pesticide transport models. Transactions of the ASAE, St. Joseph, 39(1): 47-54. 


\section{NOTES ABOUT THE AUTHORS}

Gutemberg Borges França has a degree in Physics at the Universidade Federal do Mato Grosso do Sul (UFMS/1985), a Master's degree at INPE/1988 and a PhD at University of Dundee (United Kingdom/1994). Currently is a Professor at the Meteorology Department at UFRJ and Coordinator at the Applied Meteorology Laboratory (LMA/UFRJ).

Rosa Cristhyna de Oliveira Vieira Paes has a degree in Mathematics at the Universidade Federal do Rio de Janeiro (UFRJ/1996), a Master's degree in Engineering at COPPE/UFRJ (1999) and a PhD at COPPE/UFRJ (2009). Currently is an Associate Researcher at the Applied Meteorology Laboratory (LMA/UFRJ).

Antônio do Nascimento Oliveira has a degree in Meteorology at the Universidade Federal do Rio de Janeiro (UFRJ/2008). Currently is a Master's student at the Meteorology Department at UFRJ and a researcher at the ABC Fundation (FABC).

Bianca Couto Ruivo has a degree in Computer Science at the Universidade Federal do Rio de Janeiro (UFRJ/2007). Currently is a Master's student at the Graduation Program of the Computer Science at UFRJ.

Angelo Sartori Neto has a degree in Forest Engineering at the Universidade Federal de Viçosa (UFV/1992), a Master's degree and a PhD in Remote Sensing at the same institution. Currently is an Environmental Engineer at PETROBRAS Health, Safety, Energy Efficiency and Environment Sector. 